\title{
Hastanede Yatan Çocuklarda Yaratıcı Oyun Yöntemi ile Hastalık ve Hastane Kavramı: Niteliksel Bir Çalışma
}

\section{Disease and Hospital Concept with Creative Play Method in Hospitalized Children: A Qualitative Study}

\author{
Aylin Pekyiğit ${ }^{1}$ (D), Dilek Yıldız ${ }^{2}$, Berna Eren Fidancı² (D), Burcu Çalık Bağrıyanık ${ }^{3}$ (i)
}

\author{
${ }^{1}$ Çankırı Karatekin Üniversitesi, Sağlık Bilimleri Fakültesi, Çocuk Sağlığı ve Hastalıkları Hemşireliği Anabilim Dalı, Çankırı, Türkiye \\ ${ }^{2}$ Sağlık Bilimleri Üniversitesi, Gülhane Hemşirelik Fakültesi, Çocuk Sağlığı ve Hastalıkları Hemşireliği Anabilim Dalı, Ankara, Türkiye \\ ${ }^{3}$ Ankara Yıldırım Beyazıt Üniversitesi, Sağlık Hizmetleri Meslek Yüksek Okulu, Ankara, Türkiye
}

ORCID ID: A.P. 0000-0003-2923-4452; D.Y. 0000-0001-8757-4493; B.E.F. 0000-0003-0157-6100; B.Ç.B. 0000-0002-2821-5738

Attf/Citation: Pekyigit A, Yildiz D, Eren Fidanci B, Calik Bagriyanik B. Hastanede yatan çocuklarda yaratıı oyun yöntemi ile hastalık ve hastane kavramı: Niteliksel bir çalışma. Çocuk Dergisi - Journal of Child 2021;21(2):175-182. https://doi.org/10.26650/jchild.2021.2.897005

öz

Amaç: Hastaneye yatmak, çocuklar ve aileler için korku yaratan olumsuz bir deneyimdir. Bu çalışmanın amacı hastanede yatan okul çă̆ı çocuklarının "hastalık ve hastane" hakkındaki duygu ve düşüncelerinin öğrenmektir. Gereç ve Yöntem: Çalışma bir devlet hastanesinin çocuk servisinde yatan 100 çocuk ile gerçekleştirilmiştir. Niteliksel olarak planlanan bu çalışmada hastanede yatan okul çağı çocuklarının hastalık ve hastane ilgili düşüncelerini ortaya çıkarmayı amaçlayan yaratıcı oyun yöntemi ile cümle tamamlama testi uygulanmıştır. Cümle tamamlama testine, araştırmacılar tarafından içerik analizi yapılarak tema ve kategoriler oluşturulmuştur. Çalışma için etik kurul ve gerekli izinler alınmıştır.

Bulgular: Çocuklar için sağılık-hastalık algısı, hastane deneyimi, endişeler ve hastaneden beklentiler olarak dört kategoriden oluşmaktadır. Hasta çocuklar, sağlığı kendini iyi hissetmek ve güçlü olmak, hastalığı kendini kötü hissetmek aileden, arkadaşlardan ve okuldan ayrılmak, hiçbir şey yapamamak olarak tanımlamışlardır. Hastanede yatmayı kötü, üzücü bir duygu ve korkunç bir deneyim olarak belirtmişlerdir. Hastanede aileden, okuldan, arkadaşlarından, öğretmenlerinden ayrı oldukları, derslerinden geri kaldıkları için üzüntü duyduklarını ifade etmişlerdir. Çocukların hastanedeki beklentilerinden bazıları ise kalınan odada oyuncak olması, hastanede büyük bir oyun alanının olması, okulda kaçırdığı dersleri odasından takip edebileceği bir imkan olmasıdır.

Sonuç: Araştırmamızda hastanede yatan okul çağı çocuklarının en büyük endişelerinin aileden, okuldan, arkadaşlarından ve derslerinden ayrı kalması olarak belirlenmiştir.

Anahtar Kelimeler: Hasta çocuk, hastanede yatan çocuk, yaratıcı oyun

\section{ABSTRACT}

Objective: Hospitalization is a fearful negative experience for children and families. The aim of this study is to learn the feelings and thoughts of school age children hospitalized in the hospital about "illness and hospital".

Material and Method: The study was carried out with 100 children hospitalized in the pediatric ward of a state hospital. In this qualitatively planned study, a sentence completion test was applied with the creative play method aiming to reveal the illness and hospital-related thoughts of hospitalized school-age children. In the sentence completion test, the themes and categories were created by content analysis by the researchers. Ethics committee and necessary permissions were obtained for the study.

Results: The Health-illness perception for children consists of four categories, being hospital experience, concerns, and expectations from the hospital. Sick children defined health as feeling good and strong, illness as feeling bad, leaving family, friends and school, and being unable to do anything. They reported staying in the hospital as a bad, sad feeling and a terrible experience. They stated that they regret being separated from their family, school, friends, and teachers in the hospital, and they missed their lessons. Some of the expectations of the children in the hospital are toys in the room, a large playground in the hospital, and an opportunity to follow the lessons they missed at school from their room. Conclusion: In our study, it was determined that the most important concern of school-age children who were hospitalized was their separation from family, school, friends, and lessons.

Keywords: Creative play, hospitalized child, sick child

Sorumlu Yazar/Corresponding Author: Aylin Pekyiğit E-mail: aylinpekyigit@hotmail.com

Başvuru/Submitted: 15.03.2021 • Revizyon Talebi/Revision Requested: 09.08.2021 • Son Revizyon/Last Revision Received: 09.08.2021 • Kabul/Accepted: 10.08 .2021 


\section{Giriş̧}

\section{Hastane ve Çocuk}

Hastalık ve hastaneye gitmek, çocuklar için korkutucu bir deneyim olabilir. Hastaneye yatmak ise çocukların yüzleşmek zorunda olduğu ilk krizlerdendir (1). Özellikle erken yaşlar sırasında savunmasız oldukları için hasta olmak ve hastaneye yatmak bir krize neden olabilir. Bu stresin nedeni sağlık ve çevresindeki değişim ile ilgilidir. Hastanede yatmanın çocuk üzerinde oluşturduğu majör stresörlerin nedeni, aileden ayrılma, kontrolünü kaybetmesi, bedensel yaralanma ve ağrıdır $(1,2)$.

Çocuğun hastaneye yatması gerektiğinde, tüm ailenin yaşam tarzında önemli değişiklikler meydana gelir $(1,2)$. Bu değişiklikler, tüm aile üyelerinin stres ya da kriz yaşamasına neden olur. Çocuğun hastaneye yatmaya ilişkin tepkilerini, çocuğun yaşı, gelişimsel düzeyi, hastalığın süresi ve tipi, ağrı ve hareket kısıtlılığının miktarı, önceki deneyimleri ve stresleri, ebeveynleri ile olan ilişkileri, ebeveynlerin hastaneye yatmaya hazırlaması, ağrıı işlemlerin sıklığı etkiler (3).

Çocuklar endişelerini, gerginlik, saldırganlık, iş birliği eksikliği, geri çekilme vb. davranışlarla ifade edebilir (1). Onların korku ve endişelerini azaltmak için daha önceden hastalıkları konusunda bilgilendirilmeleri ve hastane ortamını tanımaları sağlanmalıdır. Böylece tıbbi girişimler sırasında daha fazla iş birliği sergileyebilirler (4).

Çocukların hastaneyi ve hastalığı algılamaları, yorumlamaları bireysel farklılıklar gösterir. Akut hastalığa sahip bir çocuk ile kronik hastalığa sahip çocuğun hastaneye tepkisi farklı olabilir. Eğer yaşamı tehdit edici bir hastalık ise çocuk ve ailesinin anksiyete düzeyleri önemli ölçüde yüksektir (5). Fakat hastalık yanlış algılandığında ve bununla baş edilemediğinde minör bir hastalık da majör bir hastalık kadar tehlikeli olabilir (3). Bu nedenle hemşirenin, çocuğun hastanede kaldığı süre boyunca bilişsel düzeyini, hastaneye ilişkin kişisel algılamalarını, hastaneden beklentilerini, geçmiş deneyimlerini, duygu ve düşüncelerini dikkate alması gereklidir.

Çocukların hastaneye yatı̧ gibi stres faktörleriyle başa çıkmalarına yardımcı olan önemli etkenlerden biri de oyundur. Çünkü çocuklar, oyun sırasında korkularını ve endişelerini yönetilebilir bir şekilde ifade edebilirler. Hastanede yatan çocuklara en yaygın 3 oyun türü kullanılabilir (4). Bunlar; normatif, tıbbi ve terapötik oyundur.

Normatif oyun; Çocukların tipik olarak hastane dışında yaptıkları faaliyetlerdir. Örnek olarak kitap okumak, video oyunları, masa oyunları sayılabilir. Hastanedeki oyun odaları hastanede yatarak tedavi gören ve bekleme salonunda (poliklinikler gibi) çocuklara normatif oyun için firsat tanır (4).

Tibbi oyun; Oyunun basit tıbbi maddeler (örneğin, abeslang, flaster, iğnesiz enjektör, eldiven, maske vb.) kullanılarak gerçekleştirilmesidir. Çocuk eşyalarla ne yapılacağına kendisi karar verir (6).

Terapötik oyun; Spesifik hedefleri olan, oyun terapisi ilkelerini izleyerek yapılandırılmış, gerginliğin ve stresin giderilmesine yardımcı oyun türlerinden biridir (7). Terapötik oyun, çocuk hastalarda çocuğun gelişimi ve kendi duygularını ifade etmesini sağlar. Oyunların kuklalarla oynanması, çizimler, yazılar, resimler ve heykeller aracılığıyla yaratıcı ifadeler sağlarlar. Bu tür oyun ifade edilmesi gereken duyguların ifadesini gerçekleştirmek için tasarlanmış, yapılandırılmış bir oyundur (4).

\section{Terapötik Oyun Çeşitleri}

Üç çeşit terapötik oyun vardır; enerji kullanmasını sağlayan terapötik oyun, drama terapötik oyun, yaratıcı oyun şeklindedir (7).

Enerji Kullanmasını Sağlayan Terapötik Oyun; Çocukların karşılaştı̆̆ durumlarda fiziksel yeteneklerini kullanması ile gerçekleşen terapötik oyun türüdür. Çocuklar agresif duygularını davranışa dönüştürerek sergileyebilir. Örneğin; okul çağı çocuğu için bir yastı̆̆ı yumruklama yararlı olabilir $(3,8)$.

Dramatik Oyun; Çocukların taklit ederek duygularını, isteklerini ve deneyimlerini harekete geçirmelerini sağlayan terapötik oyun tipidir. Çocuk başka birinin rolüne bürünerek onun gibi davranır. Özellikle okul öncesi çocuklarda etkilidir (8). Örneğin; çocuk damar yolu açan bir hemşireyi canlandırabilir. Oyunda kullanılan aletlere dokunması sağlanabilir.

Yaratıcı Oyun; İşlemlerden önce ve/veya sonra materyal kullanarak, her prosedürün nasıl yapıldığını çocuklara göstermek için kullanılan oyun tipidir (8).

Yaratıcı oyun tipinde, resim çizme, cümle tamamlama ve üç dilek testi gibi yöntemler kullanılarak çocuğun iç dünyası hakkında bilgi toplanabilir $(3,9)$. Örneğin; öfkeyi uygunsuz bir şekilde ifade eden çocuklar için duygularını seslendiren terapötik oyunlardan yararlanabilir. Bir kukla gösterisi ile çocuklar hastaneye yatışları hakkındaki düşüncelerini ifade edebilirler. Aynı amaçla rol yapma, skeç, hikaye anlatma, resim çizdirme yazı yazdırma da kullanılabilir. Bunlar çocukların neler hissettiklerini paylaşmalarına yardımcı olabilecek yaratıcı ifadeler sağlarlar (4).

Bu çalışmadaki amacımız hastanede yatan çocuklarda terapötik oyun türlerinden yaratıcı oyun yöntemi ile hastalık ve hastane kavramının nasıl algılandığını öğrenmek ve yorumlamaktır.

\section{GEREÇ VE YÖNTEM}

\section{Araştırmanın Evreni ve Örneklemi}

Araştırmanın evrenini hastaneye yatırılan okul çağı çocukları (7-12 yaş) oluşturmaktadır. Örneklemini ise okuma-yazma bilen, araştırmaya katılmaya gönüllü çocuklar ve bu çocukların aileleri oluşturmaktadır.

\section{Araştırmanın Yapıldığı Yer ve Zaman}

Bu araştırma niteliksel bir çalışma olup 30.05.2018-30.07.2019 tarihleri arasında, bir devlet hastanesinin çocuk servisinde yatan, araştırmaya katılmaya gönüllü, 7-12 yaş arası toplam 100 okul çağı çocuğu ile gerçekleştirilmiştir.

\section{Verilerin Toplanması}

Veri toplamada araştırmacılar tarafindan literatür oluşturulan veri toplama formu kullanılmıştır $(2,3)$. Bu formda çocuğa ve 
çocuğun ailesine ait sosyodemografik özellikler (çocuğun yaşı, cinsiyeti, kardeş sayısı, hastane ile yaşanılan evin aynı ilde olup olmadığı, daha önce hastanede yatıp yatmadığı, hastaneye yatma nedeni, ebeveynlerin yaşı, eğitim durumu, çalışma durumu) ile cümle tamamlama testi yer almaktadır. Hastanede yatan okul çağı çocuklarının hastalık ve hastane ilgili düşüncelerini ortaya çıkarmayı amaçlayan cümle tamamlama testi, literatür doğrultusunda oluşturulan yaratıcı oyun tekniklerinden biridir $(2,3,9)$. Bunun için görüşmenin bölünmeyeceği, çocuğun duygu ve düşüncelerini rahatça ifade edebileceği sessiz bir oda temin edilmiştir. Görüşme sırasında isteyen ebeveynler de çocukla birlikte odaya alınmıştır. Görüşmeler veri doygunluğuna ulaşana kadar sürdürülmüştür. Tüm görüşmeler yazılı hale getirildikten sonra araştırmacılar tarafindan içerik analizi yapılarak tema ve kategoriler oluşturulmuştur.

\section{Araştırmanın Etik Yönü}

Çalışmanın yapılabilmesi için Helsinki Bildirisine uygun bir devlet üniversitesinin etik kurulundan onay alınmıştır (Onay Tarihi: 30.05.2018 ve Sayı: 36). Ayrıca ilgili ì Sağlık Müdürlüğü'nden (Onay Tarihi: 16.07.2018 ve Sayı: 39991120-799) gerekli izinler alınmıştır. Çocuklardan ve yasal vasisinden bilgilendirilmiş onam alınmıştır.

\section{Verilerin Değerlendirilmesi}

Çalışmada elde edilen sosyodemografik veriler değerlendirilirken, IBM SPSS Statistics 21 (Statistical Package for Social Sciences) paket programından yararlanılmıştır. Kategorik veriler yüzde (\%) olarak belirtilmiştir. Nitel veriler ise birbirinden bağımsız olarak üç araştırmacı tarafindan değerlendirmiştir. Bunun sonucunda kod listesi oluşturulmuştur. Oluşan kodlar sınıflandırılarak temalar ortaya çıkarılmıştır. Ifadelerin ardından belirtilen sayılar çocuklara verilen katılımcı numaralarıdır.

\section{BULGULAR}

Çalışmamızın bulgular bölümü sosyodemografik özellikler ve kategoriler başlıkları altında açıklanmıştır.

\section{Sosyodemografik Özellikler}

Araştırmaya dahil edilen çocukların yaş ortalaması 11,25 \pm 1,274 olup \%57'si erkek, \%42'si 2 kardeş olan, \%42'si daha ilköğretim 7. Sınıf öğrencisi, \%51'i hastane ile evi aynı ilde olan, $\% 51$ 'i daha önce hastanede yatmış, \%42'si alt solunum yolu enfeksiyonu tanısı ile yatan çocuklardır. Çocukların annelerinin yaş ortalaması $39,63 \pm 6,285$ olup $\% 48$ 'i ilköğretim mezunu, \%67'si çalışmayan annelerdir. Babaların ise yaş ortalaması $42,86 \pm 6,035$ olup $\% 41^{\prime} i$ lise mezunu, \%81'i çalışan babalardır. Çocuklara refakat edenler \%81 oranında anneler iken çocukların \%87'si yatış sırasında annesi ve/veya babası ile her zaman birliktedir (Tablo 1).

\section{Kategoriler ve Temalar}

Cümle tamamlama testinden elde edilen nitel veriler dört kategoriden oluşmaktadır (Tablo 2).

\section{Kategori 1: Sağlık-Hastalık Algısı}

\section{Sağlıklı olmanın anlamı "Sağlıklı olmak benim için..."}

Hastanede yatan hasta çocuklar sağlığı olmayı ağrı hissetmemek, kendini iyi hissetmek, arkadaşları ile oynayabilmek, iste- diğini yapabilmek ve mevcut hastalığını atlatabilmek şeklinde tanımlamışlardır.

"...kendini iyi hissetmek, güçlü olmak demektir." (K-3, 5, 8, 9, $10,13,15,18,24,39,45,46,57,58,60,62,64,65,66,68,73$, $74,77,78,89,90)$

“...mutlu olmaktr." (K-4, 7, 12, 21, 23, 29, 32, 38, 40, 63, 67, 71, $81,83,85,91,92,93,100)$

“...arkadaşlarımla oynayabilmektir." (K-6, 17, 43, 56, 88, 94)

“...ağrı, sızı çekmemektir.” (K-34, 37, 41, 54, 62, 79, 80)

Hasta olmanın anlamı "Hasta olmak benim için..."

Hastanede yatan hasta çocuklar hasta olmayı, kendini kötü hissetmek, hiçbir şey yapamamak, aileden ayrılmak, hastanede kalmak, mutsuzluk, endişe, üzüntü, arkadaşlarla oynayamamak, ağrı, bir engel, kısıtlanmak, hayat eksik yaşamak, sağlığın önemini anlamak, bir ceza, rahat nefes alamamak olarak tanımlamışlardır.

"...kendini kötü hissetmek, hiçbir şey yapamamak, aileden ayrılmak, hastanede kalmak demektir." (K-2, 3, 4, 5, 8, 9, 11, 14, $16,17,23,25,26,27,38,39,62,63,65,67,69,72,73,74,77$, $78,79,83,88,97,98,99)$

"...arkadaşlarımla oynayamamak demektir." (K-6, 12, 13, 15, $22,34,35,36,42,45,46,49,51,52,54,55,58,60,61,68,70$, $71,81,82,84,86,89,90)$

“...mutsuzluk, endişe, üzüntüdür." (K-4, 7, 18, 21, 24, 28, 29, 30, $32,33,40,47,50,52,85,86,91,92,93,100$ )

"Hastalığım bana annemin sözünü dinlemeyince üzüldüğümü öğretti." (K-37).

\section{Kategori 2: Hastane Deneyimi}

\section{Hastanede yatmanın anlamı "Hastanede yatmak..."}

Çocuklar hastanede yatmayı, güzel olmayan bir deneyim, kötü, üzücü, mutsuzluk, endişe verici, bunaltıcı, yıpratıcı, korkunç, sıkıcı bir duygu ve sevdiklerinden, evinden okulundan, arkadaşlarından uzak kalmak zorunda oldukları bir durum olarak belirtmişlerdir.

“...çok kötü bir duygu, beni üzüyor, bu ortamı sevmiyorum, evimi özlüyorum." (K-1, 2, 3, 4, 5, 8, 9, 14, 16, 21, 24, 26, 27, 29, 31, $32,37,39,45,55,56,61,64,66,68,79,80,83,86)$

“...hem iyi hem de kötü bir şey. Bir yandan iyileşiyorum. Diğer yandan ise evimden ve kardeşimden ayrı kalıyorum. Onları özlüyorum." (K-70)

"...o kadar da kötü değilmiş ama burada beni en çok üzen şey arkadaşlarımdan ayrılmak oldu." (K-49)

\section{Hastane hakkındaki olumlu düşünceler "Hastanedeki en iyi} deneyimim..."

Çocuklar hastanede hakkındaki olumlu düşüncelerini doktorların ve hemşirelerin sevgisi, annesinin her istediğini yapması, 
Tablo 1. Hastanede yatan çocukların tanımlayıcı özellikleri.

\begin{tabular}{|c|c|c|c|}
\hline DEĞiŞKENLER & $\%$ & DEĞiŞKENLER & $\%$ \\
\hline Çocukların cinsiyeti & & Daha önce hastanede yatma durumu & \\
\hline $\mathrm{K} \mathrm{Iz}$ & 43 & Evet & 51 \\
\hline Erkek & 57 & Hayır & 49 \\
\hline Çocukların eğitim durumları & & Hastaneye yatma nedeni & \\
\hline ilköğretim 2 & 6 & ASYE* & 42 \\
\hline İlköğretim 3 & 2 & ÜSYE** & 5 \\
\hline Illköğretim 4 & 10 & Karın ağrısı & 32 \\
\hline Illköğretim 5 & 16 & Sünnet & 4 \\
\hline Ilköğretim 6 & 24 & Apandisit & 4 \\
\hline Ilköğretim 7 & 42 & Zehirlenme & 13 \\
\hline Çocukların kardeş sayısı & & Hastane ile evin aynı ilde olma durumu & \\
\hline 0 (Kardeşi yok) & 11 & Aynı ilde & 51 \\
\hline 2 & 42 & Aynı ilde değil & 49 \\
\hline 3 & 30 & Çocukların yaşı & $11,25 \pm 1,274$ \\
\hline 4 ve üzeri & 17 & & \\
\hline Annenin eğitim durumu & & Babanın eğitim durumu & \\
\hline Okuryazar değil & 5 & Okuryazar değil & 1 \\
\hline Illköğretim & 48 & İlköğretim & 31 \\
\hline Lise & 26 & Lise & 41 \\
\hline Üniversite ve üzeri & 21 & Üniversite ve üzeri & 27 \\
\hline Annenin çalışma durumu & & Babanın çalışma durumu & \\
\hline Çalışıyor & 33 & Çalışıyor & 81 \\
\hline Çalışmıyor & 67 & Çalışmıyor & 19 \\
\hline Annenin yaşı & $39,63 \pm 6,285$ & Babanın yaşı & $42,86 \pm 6,035$ \\
\hline Refakatçi & & Yatışta ebeveynlerin durumu & \\
\hline Anne & 81 & Anne ve/veya baba ile her zaman beraber & 87 \\
\hline Anne ve baba & 6 & Sadece gece & 8 \\
\hline Kardeş & 3 & Sadece gündüz & 1 \\
\hline Diğer akraba (teyze, hala vb.) & 10 & Hiçbir zaman yok & 4 \\
\hline Toplam & 100 & Toplam & 100 \\
\hline
\end{tabular}

*Alt Solunum Yolu Enfeksiyonu, **Üst Solunum Yolu Enfeksiyonu

Tablo 2. Cümle tamamlama testinden elde edilen kategoriler ve temalar

\begin{tabular}{|c|c|}
\hline Kategoriler & Temalar \\
\hline Sağlık-Hastalık Algısı & $\begin{array}{l}\text { Sağlıklı olmanın anlamı } \\
\text { Hasta olmanın anlamı }\end{array}$ \\
\hline Hastane Deneyimi & $\begin{array}{l}\text { Hastanede yatmanın anlamı } \\
\text { Hastane hakkındaki olumlu düşünceler } \\
\text { Hastane hakkındaki olumsuz düşünceler }\end{array}$ \\
\hline Endişeler & $\begin{array}{l}\text { Aile ile ilgili endişeler } \\
\text { Okul ve arkadaş çevresi ile ilgili endişeler }\end{array}$ \\
\hline Beklentiler & $\begin{array}{l}\text { Hastalık hakkındaki beklentiler } \\
\text { Hastaneden beklentiler }\end{array}$ \\
\hline
\end{tabular}

odasındaki televizyondan çizgi film izlemesi, iyileşmeye başlaması, arkadaşlarının kendisini ziyarete gelmesi, hastalığı ile ilgili sorularına kolayca yanıt bulabilmesi, telefon ile oyunlar oynaması, başkaları ile tanışması ve birlikte oyun oynaması olarak ifade etmişlerdir.

"...hastanede yatarken doktorlar ve hemşireler beni seviyorlar, annem her istediğimi yapıyor." (K-1, 4, 6, 8, 12, 13, 14, 15 16, $24,26,27,31,32,34,35,36,38,40,42,44,47,53,60,61,63$, $64,66,76,79)$

“...odamda televizyon olması, çizgi film izlemektir." (K-1, 2, 3, $9,11,17,18,19,22,29,57,58,67,68,70,80$ ) 
“...iyileşmeye başlamam.” (K-5, 6, 23, 37, 41, 46, 48, 51, 52, 56, $62,65,71,72,72,73,75,77)$

"...hastalığım ile ilgili aklıma takılan sorulara yanıt bulabiliyorum." (K-69, 71, 78)

“...arkadaşlarımın beni ziyarete gelmesidir." (K-30, 43)

\section{Hastane hakkındaki olumsuz düşünceler "Hastanedeki en kötü} deneyimim..."

Çocuklar hastane deneyimindeki olumsuz düşüncelerini tanımlarken en çok ağrı veren işlemleri, evden ayrı kalmayı ve ebeveynlerini üzgün görmeyi ifade etmişlerdir.

"...kan alma, iğne vurulması, serum gibi canımı yakan şeyler." (K-1, 3, 5, 6, 8, 9, 11, 12, 13, 14, 151619 20, 21, 23, 25, 27, $31,32,34,36,39,41,42,43,44,45,46,51,53,54,55,56,60$, $61,63,70,71,72,73,74,75,77,78,80,83,87,88,94,95,96$, $99,100)$

“...evimden ayrı kalmaktır.” (K-52, 67, 82, 86, 89, 90)

“...annemi ağlarken görmek oldu." (K-24, 29, 48, 76)

“...midem çok bulanıyor, kusuyorum. Hastanedeki serum ve ilaçlar beni rahatlattyor ama hastanede yatmak çok yorucu, umarım bir an önce sağlığıma kavuşurum ve bir daha hastaneye hiç gelmem." (K-72)

\section{Kategori 3: Endişeler}

\section{Aile ile ilgili endişeler "Hastalandığım ve hastanede yattı̆ım için ailem..."}

Çocuklar hastane yattkkları için ailelerinin çok yorulduğunu, korktuklarını, endişelendiklerini, üzüldüklerini, kendilerini suçlu hissettiklerini, uykusuz kaldıklarını, kardeşlerinin evde yalnız kaldığını ifade etmişlerdir.

"...annem ve babam hasta olduğum için hep benimle ilgileniyor." (K-1, 2, 6, 9, 15, 33, 37, 52, 55, 58, 71, 81, 84, 86, 91, 92, 93)

"...babam çalıştı̆ı için annem de evde kardeşlerime baktı̆̆ için sadece ziyaretime gelebiliyor. Kardeşlerimle telefonda konuşuyoruz, beni merak ediyorlar ve üzülüyorlar. Ben de onları özlüyorum." (K-3, 19, 20)

“...burada beni en çok üzen şey kardeşimi görememek oldu. Annem ve babam hep yanımda, kardeşim ise gündüz ziyaretime geldi." (K-34, 72, 73, 89, 90)

Okul ve arkadaş çevresi ile ilgili endişeler "Hastanede yattğım için, okulum, derslerim, öğretmenim, arkadaşlarım..."

Çocuklar hastane yattkları için okullarını, derslerini, öğretmenlerini, arkadaşlarını özlediklerini, okulundan, derslerinden, arkadaşlarından geri kaldıklarını, arkadaşlarının ve öğretmenlerinin kendisini merak edip aramasının, ziyarete gelmesinin onları mutlu ettiğini ifade etmişlerdir.

“...okuluma gidemedim, derslerimden geri kaldım, öğretmenim, arkadaşlarım endişeleniyor, beni merak ediyorlar." (K-2, 3, 4, 5,
$8,11,12,18,19,20,21,22,24,25,26,31,32,38,41,42,43$, $46,52,56,62,70,72,77,81,88,90)$

"...hastanede yatarken arkadaşlarımın yanıma gelmesi beni rahatlatt." (K-4, 22, 24, 30)

"...öğretmenim beni merak etti ve aradı, ben iyileşince dersleri tekrar edecekmişiz." (K-18)

\section{Kategori 4: Beklentiler "Elimde sihirli bir çubuk olsaydı..."}

\section{Hastalık hakkındaki beklentiler}

Çocukların hastalık ile ilgili beklentilerini ifade ederken iyileşmeyi, rutinlerine geri dönmeyi ve hastalıkları yok etmeyi belirtmişlerdir.

"...iyileşmek, hasta olmamak, eve gitmek, herkesi iyileştirmek, bir daha hastaneye gelmemek isterdim." (K-3, 6, 7, 8, 12, 13, $14,18,21,22,23,24,25,26,27,28,29,30,31,32,33,34,35$, $36,38,39,41,42,44,45,46,48,49,50,51,52,53,54,55,56$, $57,59,60,61,62,63,64,65,66,67,68,69,70,71,72,74,75$, $76,77,78,79,82,83,84,86,87,91,92,93,97,98,99,100)$

"...mikropları yok ederdim, bütün hastalıkları yok ederdim ve hastanede uzun süre yatan çocuklara lunapark yapardım." (K-43)

\section{Hastane hakkındaki beklentiler}

Çocukların hastane ile ilgili beklentilerini, hastane odasında eğlenceli zaman geçirebilmeleri için oyuncak, internet, tablet, kitap olması, okula gidemedikleri için geri kaldıkları dersleri takip edebilecekleri bir imkan olması, girişimsel işlemlerde canlarını acıtmayan aletlerin kullanılması, ilaçların tadının tatlı olması olarak ifade etmişlerdir.

"...her çocuğun kaldığı odaya oyuncak bırakırdım." (K-1, 3, 20, $26,46,51,61,65,68,76,94,95,96)$

“...hastane odasını kendi odama çevirirdim ve bütün sevdiklerimi yanıma toplardım." (K-2, 4, 5)

“...hastanedeyken kaçırdığım konuları sihirli bir ekrandan izlemek isterdim." (K-19)

"...hastanede can yakmayan bir alet ortaya çıkarırdım. O zaman hiçbir çocuğun gözyaşı akmazdı." (K-19)

\section{TARTIŞMA}

Okul çocukları, duygusal, sosyal ve entelektüel gelişimindeki önemli ilerlemeler nedeniyle hastalık ile ilgili bilgileri, okul öncesi çocuğundan daha doğru şekilde anlayabilir ve yorumlayabilirler (2). Yapılan nitel bir çalışmada hastanede yatan çocukların çoğunun hastalıkları ile ilgili tıbbi terminolojiyi bilmediği fakat hastaneye yatma nedenlerinin, kendilerinde görülen semptomların farkında olduğu belirlenmiştir (10). Okul çağındaki hastaneye yatan çocukların hastalıkları hakkındaki düşüncelerini öğrenmek için yaratıcı oyun tekniklerinden cümle tamamlama testi bir firsat niteliğindedir. İncelenen literatür çerçevesinde yaratıcı oyun tekniklerinden biri olan cümle tamamlama tekniğinin kullanıldığı çok az sayıda araştırma bulunmaktadır. Fakat 
örneklem büyüklüğü dikkate alındığında çalışmamıza benzer bir araştırmaya rastlanmamıştır. Bu nedenlerle çalışmamıza katılım sağlayan okul çağı çocuklarından alınan çeşitli yanıtlar literatüre kazandırılmıştır.

Çalışmamızda çocuklar, sağlıklı olmayı ağrısız olma, kendini iyi hissetme, güçlü olma, arkadaşları ile oynayabilme, aile yanında vakit geçirebilme gibi günlük hayattaki rutinlerini tanımlarken hasta olmayı bunların zıtt ile açıklamışlardır. Literatürde hastanede yatan çocukların en büyük korkularının aileden ve arkadaşlarından ayrılmak, kendi kontrollerini, rutinlerini ve seçme hakkını kaybetmek olduğu yer almaktadır $(2-3,11)$. Yapılan bir araştırmada çocuklardan bazıları hastalıklarından dolayı yaşadıkları fiziksel kısıtlııkları ifade etmiştir (10). Bir başka çalışmada ise çocukların fiziksel rahatsızlığının yanı sıra, psikososyal gelişimindeki gerilemeden derin üzüntüye kadar büyük duygusal bozuklukları da beraberinde getirdiği belirlenmiştir (12). Bu doğrultuda çalışmamızda yer alan ifadeler literatür ile benzerlik göstermektedir.

Hasta olan ve hastanede yatan okul çocukları için beden fonksiyonları ile ilgili kontrolün kaybı, mahremiyete özen gösterilmemesi, ağrı, yaralanma, ölüm, arkadaşlarından ve ebeveynlerinden ayrılma kaygıya neden olur. Hastalık ve hastanede yatma, çocuğu arkadaş grubundan ayırır ve çocuğun yakın çevresinden ayrılma anksiyetesi duymasına neden olur. Aynı zamanda 6-12 yaş grubu çocuklarda hastanede yatma, kontrol kaybı ve bağımlılık duygularına neden olabilir (11). Araştırmamızda çocukların hastanede yatmaya ilişkin yüklediği anlamlar çoğunlukla çok kötü, üzücü bir duygu olduğu, evlerini ve arkadaşlarını özlediği, ortamdan hoşlanmadığı iken bazı çocuklar da çok kötü olmadığını, iyileşmelerine katkı sağladığını belirtmişlerdir. Yapılan bir çalışmada ise çocukların çoğunluğu hastane deneyimi hakkında olumlu tanımlar yapmış olmasına rağmen az da olsa olumsuz tanımlar da yer almaktadır (10). Başka bir çalışmada da benzer sonuçlar elde edilmiştir ve çocukların olumlu düşünceleri iyileşme beklentisi ve sağlık personelinin sunduğu rahatlık ile ilişkilendirilmiştir (12). Bunun yanı sıra literatürde okul çocuklarının cesur görünebilmek için korkularını saklayabilecekleri bilgisi yer almaktadır $(3,11)$. Bu doğrultuda okul çocuklarının cesur görünme arzuları da olumlu düşünceler ifade etmelerine sebep olabilir.

Sağıık çalışanları, çocukların cesur görünmek için doğru yansıtmayabileceğini göz önünde bulundurmalılardır. Örneğin; ağrılı işlemlerden sonra çocukların sözel ifadelerinin yanı sıra öykü anlattırarak ya da resim yaptırarak strese tepkilerini etkili şekilde değerlendirebilirler (11).

Çalışmamızda çocuklar hastanedeki olumlu deneyimlerini paylaşırken odasında televizyon olması, çizgi film izleyebilmesi gibi onu rahatlatıcı etkenleri ifade etmiştir. Ayrıca doktorların ve hemşirelerin onları sevdiğini, hastalıkları hakkında bilgi edinebildiklerini de eklemişlerdir. Okul çağı çocuklarında yapılan iki araştırmada da çalışmamıza benzer sonuçlar elde edilmiştir ve çocukları çoğu hastanede hemşireler tarafindan iyi bakıldığını, iyileştirildiğini ve sevildiklerini söylemişlerdir $(10,12)$. Yapılan başka nitel bir çalışmada çocuklar, hastanedeki hemşirelik ba- kımına karşı olumlu duygular beslediklerini ifade etmişlerdir (13). Çalışmamızla benzer olan bu tür çalışmalardan, sağlık profesyonellerinin çocuklarla kurduğu olumlu iletişimin, hastane deneyimini anlamalarına yardımcı olduğu sonucu çıkmaktadır.

Çalışmamızda yer alan "Hastalığım bana annemin sözünü dinlemeyince üzüldügümü öğretti." ifadesinde çocuğun tibbi tanısı hakkında bilgisi olmadığı, hastalığı bir ceza olarak algıladığı çıkarımı yapılmıştır. Literatürde okul çağı çocuklarının da hastalıkları hakkında bilgi ihtiyacı bulunduğu, anlayabilecek yeterliliğe sahip olduğu ve karşılanması gerektiği yer almaktadır $(2,3)$. Yapılan bir başka çalışmada da çocukların çoğunun tıbbi tanısını bilmedikleri belirlenmiştir (10). Ebeveynler ise bilgi vermemeyi tercih edebilirler. Fakat çocuklar, hastanede yatmanın rutinlerinden tamamen farklı bir durum olduğunun ve gerçekte ne olduğunu anlamak için açıklamaya ihtiyaçları olduğunun farkındadır. Bu bilgiler çocuğun güvenliğini artırarak, başa çıkmasını kolaylaştıracaktır $(12,14)$. Literatür çocukların, ailesi ve sağlık profesyonelleri tarafindan bilgilendirilmesi gerektiğini öne sürmektedir (2). Çocuklara bilgi vermek için çeşitli seçenekler bulunmaktadır. Çizgi film izleme, kitap okuma, oyun oynama veya tıbbi bir işlem yaparken müzik dinleme dikkati başka yöne çekme teknikleri arasında yer alır (15). Çocuğun tıbbi prosedürlerle baş etmesine yardımcı olmasının yanı sıra, onları bilgilendirmek için de kullanılabilir.

Çalışmamızda çocuklar hastanede yaşadıkları en kötü deneyimleri arasında çoğunlukla ağrı verici işlemleri tanımlarken bir kısmı da verilen tedavi ve bakımın onu rahatlattı̆ını belirtmişlerdir. Ağrılı işlemler çocuklarda endişe ve korkuya neden olabilir. Çocukların yaşadığı korkular, tedavi ve bakım işlemlerine katılma konusunda isteksizliğe neden olabilir $(16,17)$. Buna engel olabilmek veya bu durumu en aza indirebilmek için birçok yöntem kullanılabilir. Basitçe uygulanabilen dikkati başka yöne çekme uygulamaları sayesinde çocukların ağrı ve korkuları azaltılabilir $(17,18)$. Hastanın korkusunu azaltmak, tedaviye uyumunu, olumlu başa çıkma yeteneklerini ve yaşam kalitesini artırır (17). Yapılan bir çalışmada hastanede yatan okul öncesi (3-6 yaş) ve okul çağı çocuklarına (7-12 yaş) uygulanan terapötik oyunun kan alma gibi ağrılı girişimlerde ağrıya ve anksiyeteye etkisi değerlendirilmiştir. Uygulamada bir oyuncak bebek üzerinde kan alma tekniği gösterilmiştir ve çocuktan da göstermesi istenilmiştir. Çalışma bulguları terapötik oyunun çocuklarda yaşanan ağrı ve anksiyeteyi azalttı̆̆ belirlenmiştir (7). Bu tür ağrıyı ve anksiyeteyi kontrol etmeye ilişkin çalışmalar literatürde geniş bir yere sahiptir. Kanıt düzeyi yüksek çalışmalardan elde edilen bilgiler kullanılarak çocuklar ağrılı işlemlere hazırlanmalıdır.

Çalışma bulgularımızda çocukların endişelerini ifade ederken en çok ailesinden, evinden, okuldan, arkadaşlarından, derslerinde ayrı kaldığı, başarısız olmaktan endişe duydukları belirlenmiştir. Evdeki kardeşlerini, anne veya babalarını, ev ortamını, okuldaki arkadaşlarını ve öğretmenlerini özlediklerini ifade etmişlerdir. Hastanede yatarken kardeşlerinin, sevdiklerinin, arkadaşlarının ve öğretmenlerinin araması, ziyaretine gelmesi onları mutlu etmiştir. Yapılan bir araştırmada hastanede yatan çocukların benzer ifadelerde bulunduğu ve çocukların temas kuramadıkları sevdiklerinden dolayı yalnızlık yaşamakta oldukları belirlenmiş- 
tir $(12,13)$. Literatürde okul çocukluğu döneminde başarının ve arkadaş gruplarının önem taşıdığı ve hasta iken büyük bir endişe oluşturduğuna dair bilgiler yer almaktadır $(2,3)$. Okul çağı yaş grubundaki çocuğun dünyasında okulun çok önemli bir yeri vardır. Hasta olma ve hastanede yatma nedeniyle okula devam edememesi stres yaratır (11). Çalışmamızda da "...hastanedeyken kaçırdığım konuları sihirli bir ekrandan izlemek isterdim." ifadesi yer almaktadır. Yapılan bir çalışmada hastanede yatan çocukların hastaneden beklentileri arasında okul da yer almaktadır (10). Çalışmamızdan elde edilen bulgular literatürdeki bu bilgileri doğrular niteliktedir. Çocukların çoğunluğu gelişimsel özelliklerini endişeleri ile de yansıtmaktadır.

Hastanede yatmanın çocuk üzerinde oluşturduğu majör stresörler arasında aileden ayrılma da yer almaktadır $(1,2)$. Normalde okul çağı çocukları ayrılmayla iyi baş edebilirler. Fakat hastanede yatmaya bağlı yaşadıkları stres, ebeveynlerine olan ihtiyacı artırabilir (2). Çocukların hastaneye uyumu, kaygı ve streslerinin azaltılması için tıbbi ortamın normalleştirilmesi sağlanabilir. Tıbbi ortamın normalleştirilmesi, hastane ortamını hastane dışındaki yaşama benzer hale getiren faaliyetlerdir. Çocukların rutinlerini uygulamalarına firsat tanır. Örneğin, aile filmi gecesi yapılabilir (4). Böylece hastane ile ilgili olumlu deneyimler de edinebilirler.

Çocukların hastalık ile ilgili beklentileri arasında iyileşmek, eve gitmek, hasta olmamak, herkesi iyileştirmek ve bir daha hastaneye gelmemek yer almaktadır. Çocuklar hastane ile ilgili beklentileri arasında okula gidemedikleri için geri kaldıkları dersleri takip edebilecekleri bir imkan olması, girişimsel işlemlerde canlarını acıtmayan aletlerin kullanılması, ilaçların tadının tatlı olması yer almaktadır. Ayrıca çocuklar çoğunlukla hastane odasında oyuncak, internet, tablet ve kitap olmasını istemişlerdir. Çocuklar, kuklalar, kitaplar, bebekler gibi oyuncaklar ile oynayarak, stresli bir olayla ilişkili duygularını ifade edebilirler. Örneğin, "doktora görünmekten korkuyorum" gibi ifadeleri kukla oyunu ile dile getirebilir. Böylece uyarlanabilir davranış zamanla içselleştirilir ve tepki haline gelebilir (4). Hastanede yatan çocukların duygu ve düşüncelerini öğrenebilmek için bir araç olarak kullanılabilir. Bu nedenle oyun çocuğun hayatında önemli bir yere sahiptir.

Oyun sırasında çocuklar, stresli durumlarla ilişkili yoğun duyguları parçalar halinde yaşayabilirler. Duygularını yansıtırken bir kerede değil, daha küçük, daha uygulanabilir halde ifade edebilirler (19). Oyun, çocukların stresle baş etmek için kullandıkları temel araçlardan biridir (20). Hemşireler, stres ve kaygıyı hafifletmek için hastaların günlük rutinlerine oyun oynama gibi aktiviteler ekleyebilir (17). Böylece hastanede yatan çocuğun, baş etme becerisi geliştirmesine yardımcı olabilirler.

Kültürel ve çevresel faktörler ne olursa olsun çocuklar oyun oynamak için bir yol bulurlar. Çocuklar oyun sayesinde kendilerini özgürce ifade etme firsat bulurlar. Anlam veremedikleri konuları güvenle araştırır, gelişimsel beceriler ve yetkinlikler geliştirir. Çocukların oyun aracılığı ile tıbbi ortamı anlayabilmeleri, eğlenceli aktivitelerle baş etme becerilerinin gelişmesine, kendilerini ifade edebilme yeteneklerine katkıda bulunur $(4,20)$.
Çocuğa işlemler açıklanırken farklı oyun türlerinden yararlanılabilir. Oyun türleri birbirinden tamamen ayrı değildir. Hastanede yatan çocukların ihtiyaçlarının değerlendirilmesinde üç oyun türünün hepsi de kullanılabilir. Örneğin; kanser tanısı konmuş bir çocuğa tıbbi prosedürlere hazırlık olarak tıbbi oyundan, tıbbi prosedürler sırasında biraz eğlendirmek normatif oyundan, okuldan ve akranlardan ayrılmayla ilgili bazı hayal kırıklıklarını ifade etmesini sağlamak için terapötik oyundan yararlanılabilir (4). Yapılan deneysel bir çalışmada preoperatif dönemde 7-12 yaş arası 203 çocuğa ameliyathane, anestezi odası, ayılma odası gezdirilmiştir. İ̧̧lem oyuncak bebek üzerinde gösterilmiş, postoperatif ağrı ve anksiyetesi ölçülmüştür. Deney grubundaki ailelerin ve çocuklarının kontrol gurubuna göre anksiyeteleri, çocukların ağrı puanları daha düşük bulunmuştur (21). Yapılan başka bir randomize kontrollü çalışmada, konjenital kalp ameliyat olacak 6-12 yaş arası çocuklara preoperatif dönemde terapötik oyun ile eğitim verilmiştir. Anne-çocuk deney grubuna dahil edilmiştir. Sağlanan eğitimin, postoperatif dönemde çocukların ve annelerinin kaygı düzeylerini azalttı̆ı belirlenmiştir (22). Bir başka çalışmada kullanılan terapötik oyunun çocuklarda oluşan anksiyete, korku ve ağrı düzeyini azaltmada etkili olduğu belirlenmiştir (23). Diğer bir çalışmada çocukların hastanede park, oyun odası, sinema odası, bilgisayar ve ilköğretim odası istedikleri yer almaktadır (10). Çalışmamızda da benzer olarak "...hastanede uzun süre yatan çocuklara lunapark yapardım.", "...her çocuğun kaldığı odaya oyuncak bırakırdım." gibi ifadeler yer almaktadır. Çocuk servisleri ve hastanelerinin fiziksel özellikleri, çocuk ve aileler için rahatlatıcı ve güven verici olmalıdır (5). Çalışmamızda çocukların beklentilerinin gelişimsel özelliklerine yönelik ihtiyaçlarını içerdiği belirlenmiştir ve özellikle okul çağı çocuğunun okuldan geri kaldığı için derslerinden başarısız olma endişeleri bulunmaktadır. Bu endişeyi en aza indirebilmek için çocukların okula devam edemedikleri dönemlerde yararlanabilecekleri hastane okulunun olması önemlidir.

\section{SONUÇ}

Sonuç olarak; çalışmamızda çocuklar, sağlıklı olmayı ağrısız olma, kendini iyi hissetme, güçlü olma, arkadaşları ile özgürce oynayabilme, aile yanında vakit geçirebilme, hasta olmayı da bunların zıtt ile açıklamışlardır. Çocukların hastanede yatmaya ilişkin yüklediği anlamlar ise çoğunlukla kötü duygularla eşleşmektedir. Hastanedeki olumlu deneyimlerini paylaşırken odasında televizyon olması, çizgi film izleyebilmesi gibi onu rahatlatıcı etkenleri ifade etmiştir. Hastanede yaşadıkları en kötü deneyimleri arasında çoğunlukla ağrı verici işlemleri tanımlarken bir kısmı da verilen tedavi ve bakımın onu rahatlattı̆ını belirtmişlerdir. Çocuklar endişelerini ifade ederken en çok ailesinden, evinden, okuldan, arkadaşlarından, derslerinden ayrı kaldığını, başarısız olmaktan endişe duyduklarını belirtmişlerdir. Evdeki kardeşlerini, anne veya babalarını, ev ortamını, okuldaki arkadaşlarını ve öğretmenlerini özlediklerini ifade etmişlerdir. Çocukların hastalık ile ilgili beklentileri arasında iyileşmek yer alırken Çocuklar hastane ile ilgili beklentileri arasında okula gidemedikleri için geri kaldıkları dersleri takip edebilecekleri bir imkan olması yer almaktadır. Bu sonuçlar doğrultusunda çocukların hastalık ve hastaneye uyumunun sağlanması için televizyon, çizgi film, kitap, oyuncak vb. materyallerden yarar- 
lanılabilir. Ayrıca bu materyaller ağrının kontrolü için de kullanılabilir. Günlük rutinlerinin önem taşıdığı bu yaşta mümkün olduğunca hastanede aile ziyaretine yer verilmelidir. Okul çağı çocuğu için önemli bir yere sahip olan arkadaşları ve öğretmeni ile iletişimini sürdürmesi sağlanmalıdır ve derslerinin takibi için mevcut teknoloji kullanılmalıdır.

Etik Komite Onayı: Helsinki Bildirisine uygun bir devlet üniversitesinin etik kurulundan onay alınmıştı (Onay Tarihi: 30.05.2018 ve Sayı: 36).

Bilgilendirilmiş Onam: Katlımcılardan bilgilendirilmiş onam alınmıştır.

Hakem Değerlendirmesi: Dış bağımsız.

Yazar Katkıları: Çalışma Konsepti/Tasarım- A.P.; Veri Analizi/YorumlamaA.P., D.Y., B.E.F.; İçeriğin Eleştirel İncelemesi- A.P., D.Y., B.E.F., B.Ç.B.; Son Onay ve Sorumluluk- A.P., D.Y., B.E.F., B.Ç.B.

Çıkar Çatışması: Yazarlar çıkar çatışması beyan etmemişlerdir.

Finansal Destek: Yazarlar finansal destek beyan etmemişlerdir.

Ethics Committee Approval: This study was approved by the ethics committee of a state university in accordance with the Declaration of Helsinki (Approval Date: 30.05.2018 and Number: 36).

Informed Consent: Written consent was obtained from the participants.

Peer Review: Externally peer-reviewed.

Author Contributions: Conception/Design of Study- A.P.; Data Analysis/ Interpretation- A.P., D.Y., B.E.F.; Critical Revision of Manuscript- A.P., D.Y., B.E.F., B.Ç.B.; Final Approval and Accountability- A.P., D.Y., B.E.F., B.Ç.B.

Conflict of Interest: Authors declared no conflict of interest.

Financial Disclosure: Authors declared no financial support.

\section{KAYNAKLAR/REFERENCES}

1. Favara-Scacco C, Smirne G, Schilirò G, Di Cataldo A. Art therapy as support for children with leukemia during painful procedures. Med Pediatr Oncol 2001;36(4):474-80.

2. Merck T, McElfresh P. Family-Centered Care of the Child During IIIness and Hospitalization. In: Hockenberry MJ, Wilson D, Rodgers CC. Ed., Wong's Essentials of Pediatric Nursing, Tenth Edition, Elsevier; 2017. p. 554-571.

3. Çavuşoğlu H. Çocuk Sağlığı Hemşireliği, 12. Baskı, 1. Cilt, Ankara: Sistem Ofset Basımevi; 2019.

4. Burns-Nader S. Hernandez-Reif M. Facilitating play for hospitalized children through child life services. Children's Health Care 2016;45;1-21.

5. Cimete G, Kuğuoğlu S, Çınar NS. Çocuk, Hastalık, Hastane Ortamı. İ̧̧inden: Conk Z, Başbakkal Z, Bal Yılmaz H, Bolışık B, Ed., Pediatri Hemşireliği. Ankara: Akademisyen Tıp Kitabevi; 2013.

6. Li WHC, Chung JOK, Ho KY, Kwok BMC. Play interventions to reduce anxiety and negative emotions in hospitalized children. BMC Pediatrics 2016;16:36-44.
7. Lemos ICS, Silva LG, Delmondes GA, Brasil AX, Santos PLF, Gomes $E$, et al. Therapeutic play use in children under the venipucture : $A$ strategy for pain reduction. American Journal of Nursing Research 2016;4(1):1-5.

8. Caleffi CCF, Rocha PK, Anders JC, Souza AIJ, Burciaga VB, Serapião LS. Contribution of structured therapeutic play in a nursing care model for hospitalised children. Revista Gaucha De Enfermagem 2016;37(2):1-8.

9. Foote JM. Communication and Physical Assessment of the Child and Family. In: Hockenberry MJ, Wilson D, Rodgers CC. Ed., Wong's Essentials of Pediatric Nursing, Tenth Edition, Elsevier; 2017. p.5767.

10. Akkavak DT, Karabudak SS. Hastanede Yatan Okul Çağı Çocukların Hemşireyi ve Hastaneyi Algılama Durumlarının İncelenmesi. DEUHFED 2019;12(1):46-56.

11. Sanders J. Family-Centered Care of the Child During Illness and Hospitalization. In: Hockenberry MJ, Wilson D, Ed., Wong's Essentials of Pediatric Nursing, Eighth Edition, Elsevier. 2009.

12. Lima LN, Carvalho EO, Batista V, Melo MC. Self-reported experience of hospitalized children: an integrative review. Rev Bras Enferm 2020;73(Suppl 4):e20180740.

13. Pena ANL, Juan LC. The experience of hospitalized children regarding their interactions with nursing professionals. Review Latino-Americano Enfermagem 2011;19(6):1429-36.

14. Flowers SR, Birnie KA. Procedural preparation and support as a standard of care in pediatric oncology. Pediatric Blood and Cancer 2015;62(Suppl. 5):694-723.

15. McMurtry M, Chambers C, McGrath P, Asp E. When "don't worry" communicates fear: Children's perceptions of parental reassurance and distraction during a painful medical procedure. Pain 2010;150(1):52-8.

16. Sahiner NC, Bal MD. The effects of three different distraction methods on pain and anxiety in children. J Child Health Care 2016;20(3):277-85.

17. Schleisman A, Mahon E. Creative Play A nursing intervention for children and adults with cancer, Clinical Journal of Oncology Nursing 2018;22(2):137-40.

18. Barkey ME, Stephens B. Comfort measures during invasive procedures: The role of the child life specialists. Child Life Focus 2000;2(1):1-4.

19. Moore M, Russ S. Pretend play as a resource for children: Implications for pediatricians and health professionals. Journal of Developmental and Behavioral Pediatrics 2006;27(3):237-48.

20. Nabors L, Bartz J, Kichler J, Sievers R, Elkins R, Pangallo J. Play as a mechanism for working through medical trauma for children with medical illnesses and their siblings. Issues in Comprehensive Pediatric Nursing 2013;36(3):212-24.

21. Li HCW, Lopez V. Effectiveness and appropriateness of therapeutic play intervention in preparing children for surgery: A randomized controlled trial study. Journal for Specialists in Pediatric Nursing 2008;13(2):63-73.

22. Coşkuntürk AE, Gözen D. The Effect of Interactive Therapeutic Play Education Program on Anxiety Levels of Children Undergoing Cardiac Surgery and Their Mothers. J Perianesth Nurs 2018;2.

23. Buyuk ET, Bolışık B. The Effect of Preoperative Training and Therapeutic Play on Children's Anxiety, Fear and Pain. Journal of Pediatric Surgical Nursing 2015;4(2):78-85. 